\title{
SUPPLY CHAIN MANAGEMENT AS A COMPETITIVE ADVANTAGE IN THE SPANISH GROCERY SECTOR
}

\author{
CRISTINA GIMÉNEZ \\ EVA VENTURA $^{\dagger}$ \\ GREL-IET; Universitat Pompeu Fabra*
}

\begin{abstract}
Adversarial relationships have long dominated business relationships, but Supply Chain Management (SCM) entails a new perspective. SCM requires a movement away from arms-length relationships toward partnership style relations.

SCM involves integration, co-ordination and collaboration across organisations and throughout the supply chain. It means that SCM requires internal (intraorganisational) and external (interorganisational) integration.

This paper analyses the relationship between internal and external integration processes, their effect on firms' performance and their contribution to the achievement of a competitive advantage. Performance improvements are analysed through costs, stock out and lead time reductions. And, the achievement of a better competitive position is measured by comparing the firm's performance with its competitors' performance. To analyse this, an empirical study has been conducted in the Spanish grocery sector.
\end{abstract}

\section{Keywords}

Supply Chain Management; Logistics integration processes; Internal and external integration; Competitive advantage; Logistics performance

JEL codes: L290,L660,C120,C490

\footnotetext{
${ }^{\dagger}$ The authors thank the members of GREL-IET for their comments and suggestions. Eva Ventura acknowledges financial support from research grants SEC2001-0769 and BEC2000-0983.

*Address for corresponding author: Cristina Giménez Thomsen. Departament d'Economia I Empresa. UPF. Ramon Trias Fargas, 25-27, 08005 Barcelona, Spain. Phone: 34-935422901. Fax: 34-935421746. E-mail: cristina.gimenez@econ.upf.es.
} 


\section{Introduction}

During the last fifteen years the Spanish grocery sector has evolved and modernised considerably. There has been a growth in the implementation of new technologies (such as EPOS -Electronic Point of Sales- and EDI -Electronic Data Interchange-) and the development of new commercial formats (such as hypermarkets and supermarkets). The most important characteristics of this sector are: its high concentration level (in 2000, the first five groups had a market share of $50 \%$ approximately; Distribución Anual, 2002), the considerable presence of foreign capital, and the increase in the market share of the new commercial formats (supermarkets and hypermarkets).

The highly competitive environment of the grocery-retailing sector has made companies look for a competitive advantage. Logistics management has the potential to assist the organisation in the achievement of both a cost/productivity advantage and a value advantage (Christopher, 1998). But, the logistics perspective that considers the company itself without considering its supply chain members is not sufficient. To gain this competitive advantage, there is the need to adopt the Supply Chain Management (SCM) approach and consider the supply chain as a whole.

Supply Chain Management (SCM) is "the management of upstream and downstream relationships with suppliers and customers to deliver superior customer value at less cost to the supply chain as a whole" (Christopher, 1998). This philosophy requires a movement away from arms-length relationships toward partnership-style arrangements.

SCM involves integration, co-ordination and collaboration across organisations and throughout the supply chain. It means that SCM requires internal (intraorganisational) and external (interorganisational) integration.

Stevens (1989) suggests that firms must achieve a relatively high degree of internal integration (collaboration among internal processes) before implementing SCM. To develop an integrated supply chain it is essential to evolve through a number of stages (see figure 1). 
FIGURE 1. Logistics evolution: From distribution logistics to supply chain

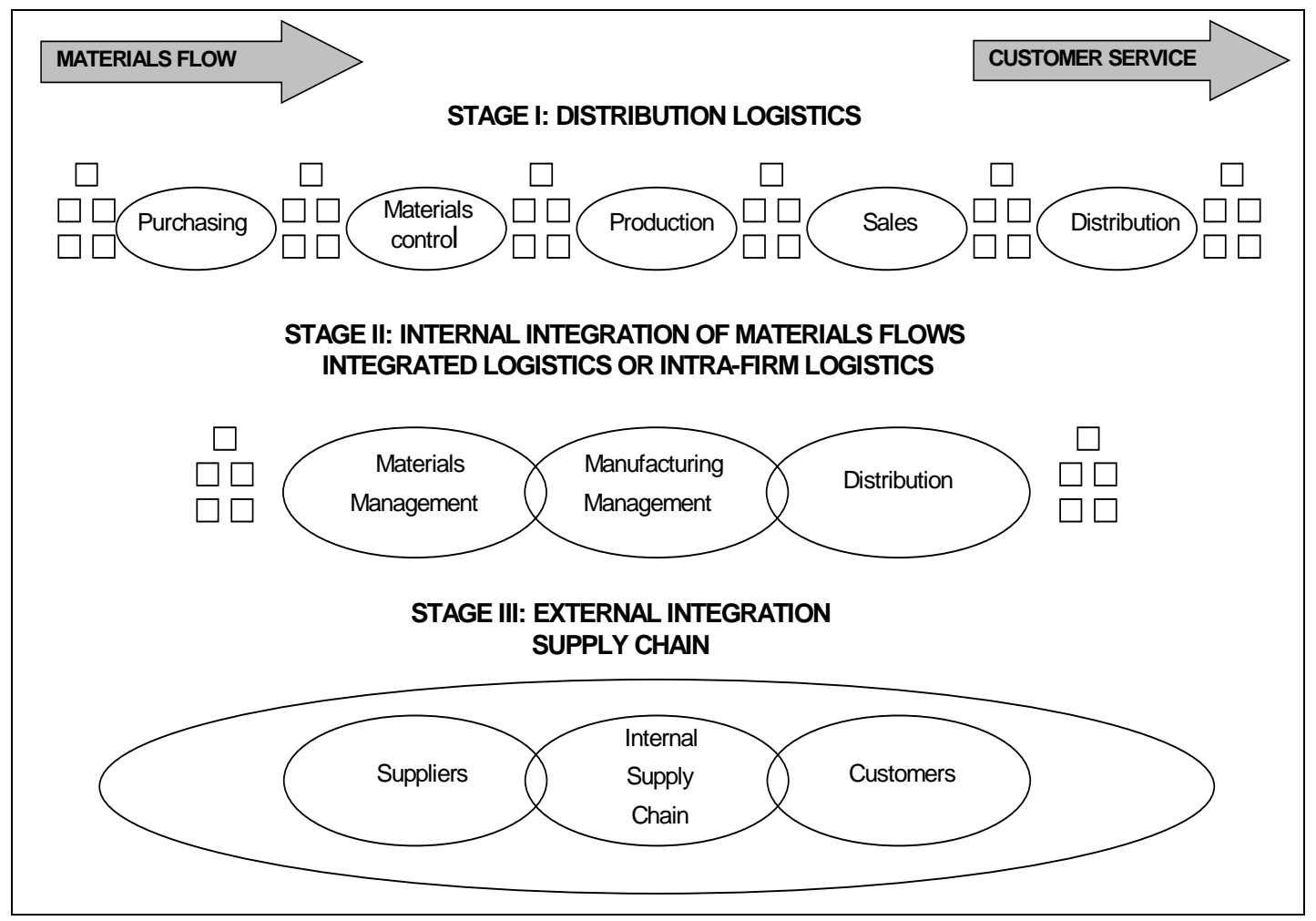

Source: Adapted from Stevens, G.C. (1989): "Integrating the Supply Chain"; International Journal of Physical Distribution and Materials Management; Vol. 19 no. 8; pages 3-8.

In stage I, the logistics function is seen merely as a distribution function, separated from the rest of the organisational functions. In stage II, there is an integration of the various components of logistics within the firm's boundaries. And, finally, in stage III the internal integration (achieved in the previous stage) is extended to suppliers and customers.

In this paper, we consider internal and external integration and explore how they are related to each other and to the relative and absolute performance of the firm. Here, internal integration is the integration across functional boundaries within a firm. The level of internal integration is reflected by the extent to which logistics activities interact with other functional areas, as well as by the extent to which logistics is or is not a separate functional unit (Stock, Greis \& Kasarda, 1998).

We follow Stock, Greis \& Kasarda (1998) and define external integration as the integration of logistics activities across firm boundaries. It is to think of the manufacturing enterprise in terms of the entire supply chain, which increasingly consists of many separate firms banded together in network arrangements.

To explore the integration-performance relationship, it is necessary to measure firms' performance, which can be analysed in absolute and relative terms. Absolute 
performance refers to the performance considering the company itself, not taking into account its competitors' performance. Costs, stock-outs and lead-time reductions are some measures of absolute performance. The aim of analysing performance in absolute terms is to determine which improvements can be achieved by implementing a logistics integration program.

A firm gains competitive advantage by performing strategically important activities more cheaply or better than its competitors (Porter, 1985). The contribution of SCM to gaining a competitive advantage is embedded in the concept of relative performance, which can be measured by asking the company to compare its performance with that of its competitors'.

It is necessary to measure performance in absolute and relative terms, because a logistics integration program can lead to cost reductions, but it may not lead to a better competitive position.

Many authors claim that Supply Chain Management and information sharing can substantially involve better supply chain performance (Shapiro, 1984; Scott \& Westbrook, 1991; Byrne \& Javad, 1992; Cooper, 1993; Ellram \& Cooper, 1993; Gustin, Stank \& Daugherty, 1994; The Global Research Team at Michigan State University, 1995; Christopher, 1998; and Christiansee \& Kumar, 2000). But few empirical studies have been conducted to demonstrate this (Vargas, Cardenas \& Mattarranz, 2000, and Stank, Keller \& Daugherty, 2001).

Vargas, Cardenas \& Matarranz (2000) analysed the integration activities of leading Spanish assembly manufacturing firms. Their results showed that Spanish firms rely more on internal rather than external integration activities as means for achieving strategic goals. The main conclusion was that logistics integration programs do provide a competitive and economic advantage, although still at a low potential level. However, this study has some limitations: First, the simultaneous effect of both levels of integration was not considered. And, second, the level of internal integration was determined by variables such as the level of implementation of JIT, TQM (Total Quality Management) and Kaizen programs, not considering the level of interaction between functional areas, such as Production and Logistics.

The study of Stank, Keller \& Daugherty (2001) is based on the results of a survey mailed in late 1998 to manufacturers, wholesalers and retailers listed in the Council of Logistics Management member list. The main conclusions of this study are: (1) internal and external collaboration are positively correlated, (2) internal collaboration leads to a better competitive position in some logistics service performance variables (speed, 
dependability, responsiveness, flexibility and overall customer satisfaction), and (3) external collaboration does not lead directly to better outcomes in logistics service. However, this study has three main limitations: (1) Only service elements were included in the performance construct (any cost element was not included); (2) performance was only measured in relative terms (absolute performance was not considered); and (3) a unique external integration level was assigned to each company (when a company has usually a different level of external integration in each relationship).

There are other empirical studies that analyse the separated effect of internal or external integration programs on performance. The studies considering only the internal integration-performance relationship are Daugherty, Ellinger \& Gustin, 1998; Ellinger, Daugherty \& Keller, 2000 and Stank, Daugherty \& Ellinger, 2000. And, the studies analysing only the external integration-performance relationship are: Daugherty, Sabath \& Rogers, 1992; Larson, 1994; Daugherty, Ellinger \& Rogers, 1995; Groves \& Valsamakis, 1998; Stank, Crum \& Arango, 1999; Stank, Daugherty \& Autry, 1999; Ellinger, Taylor \& Daugherty, 2000 and Scannell, Vickery \& Dröge, 2000.

We plan to contribute to the existing empirical research on the relationship between SCM and performance by:

1. Analysing performance improvements in absolute and relative terms.

2. Analysing the contribution of both levels of integration (internal and external) to improving firms' performance.

3. Including measures of service and cost in the logistics performance constructs.

The paper is organised as follows. Section 2 describes the data, model and statistical analysis. The results are presented in section 3. And, section 4 concludes. Also, some details related to the description and previous exploration of the data are gathered in the Appendix.

\section{Data and Model Specification}

The research involved an explicative study based on the results of a survey, which was conducted during the spring-summer of year 2001. The questionnaire was sent to manufacturers of the Spanish grocery sector. These companies were selected from de Fomento de la Producción España 25.000 database. We restricted ourselves to the Manufacturers of the food and perfumery-detergent sectors and chose those companies with a sales figure in 1999 higher than 30 million euros. Due to the need of limiting the scope of the study, we focused primarily on the manufacturer-retailer 
relationships, not considering any other supply chain member or supply chain relationship within the grocery supply chain (such as third party logistics, wholesalers, purchasing centres and manufacturers' suppliers).

The resulting sample had 199 manufacturers. Given the strategic focus of the research, it was decided to mail questionnaires to the logistics or supply chain executive of each firm. Early notification of prospective respondents is believed to increase response rates (Fox, Crask \& Kim, 1988). And, accordingly, all companies were telephoned and asked for permission to mail the questionnaire. From the 199 manufacturers, only one company refused to participate in the study.

The number of logistics managers who responded to the first mailing was 50 . Another 14 responded to a second mailing sent to the 148 managers who had not responded after four weeks. The total number of responses was 64 , which represents a response rate of $32,3 \%$. Potential participants were asked to provide sensitive and confidential data about their performance, so the response rate of $32,3 \%$ is considered very satisfactory especially when compared to the response rate of other studies. For example, Groves \& Valsamakis (1998) used data from a survey with a response rate of 15\%; Stank, Daugherty \& Autry (1999) obtained a 20,2\% response rate, and Stank, Keller \& Daugherty (2001) worked with a response rate of $11,5 \%$. Taking into account sales volumes, we obtained responses from companies that represented $44,06 \%$ of the sample's sales volume. The characteristics of the companies answering the questionnaire are shown in table $\mathrm{A} 1$ of the Appendix.

We conducted an analysis of non-response bias based on the procedure described in Armstrong and Overton (1977) and Lambert and Harrington (1990). Responses were numbered sequentially in the order they were received, and lately responses were compared with early responses. No noticeable pattern among the variables could be detected to indicate the existence of a non-response bias. Accordingly, non-response bias is unlikely to be an issue in interpreting the results of this study.

Figure 2 shows the proposed relationship between Internal and External Integration, and the Performance of the firm, as explained in section 1. Three latent variables or factors are related in a causal way. Both Internal Integration in the LogisticsProduction interface and External Integration are supposed to affect firm's performance (absolute or relative). Also, Internal Integration in the LogisticsProduction interface is supposed to be correlated with External Integration. 


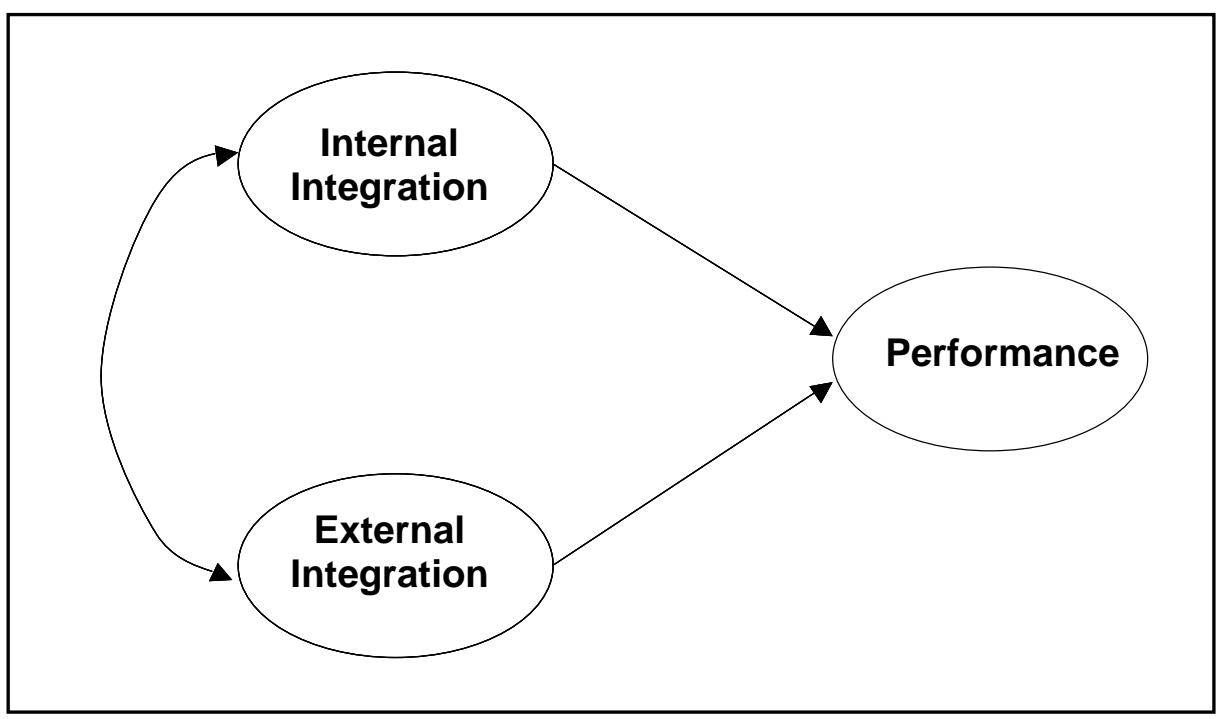

Structural Equations Modelling (SEM) is appropriate for the simultaneous assessment of the relationships between multiple dependent and independent latent constructs. Moreover, SEM is particularly useful when moving from exploratory to confirmatory analysis. For these reasons, this method is appropriate for analysing the relationships between the constructs of interest (Hair, Anderson, Tatham \& Black, 1999). Figure 2 depicts a simple Factor Analysis model that can be easily estimated with a program such as EQS ${ }^{1}$ (see Bentler, 1995).

The data survey included seven questions intended to measure the level of internal integration for each company in the Logistics-Production interface. The questionnaire also included eight variables that would measure the level of external integration. But, as the level of external integration should be referred to a particular relationship and not to the company, each interviewed person was asked to think of two manufacturerretailer relationships of his/her company. The first relationship had to be the most collaborating one, while the second should be the least collaborating relationship. Therefore, the eight questions related to external integration were asked twice, for each one of the two manufacturer-retailer relationships considered. Then, each manufacturer was asked about the performance of each relationship (the most and least collaborating relationships). The questionnaire included six variables to assess the relative performance and five items to measure the absolute performance. Table 1 shows the variables originally designed to measure the integration levels and the relationships' performance.

\footnotetext{
${ }^{1}$ There is plenty of other very good software in Structural Equations Modelling. See for example LISREL (Jöreskog \& Sörbom, 1993), AMOS (Arbuckle, 1997), or CALIS (SAS Institute, 1990) among others.
} 


\section{VARIABLES}

Internal Integration (scale of 1 to 10)

Il1: Informal teamwork

II2: Shared ideas, information and other resources

II3: Established teamwork

II4: Joint planning to anticipate and resolve operative problems

II5: Joint establishment of objectives

II6: Joint development of the responsibilities' understanding

II7: Joint decisions about ways to improve cost efficiencies

External Integration (scale of 1 to 10 )

El1: Informal teamwork

EI2: Shared information about sales forecasts, sales and stock levels

EI3: Joint development of logistics processes

El4: Established work team for the implementation and development of continuous replenishment programs (CRP) or other ECR practice

EI5: Joint planning to anticipate and resolve operative problems

El6: Joint establishment of objectives

EI7: Joint development of the responsibilities' understanding

El8: Joint decisions about ways to improve cost efficiencies

Absolute Performance (scale of 1 to 10 )

AP1: My company has achieved a reduction in the cost-to-serve this customer

AP2: My company has achieved cost reductions in the transport to this customer

AP3: My company has achieved cost reductions in the order process of this customer

AP4: My company has achieved stock-out reductions in the products this customer buys

AP5: My company has achieved a lead time reduction for this customer

Relative Performance (scale of 1 to 5 )

RP1: My company responds to this customer's needs and requirements

RP2: My company responds to special requirements of this customer

RP3: My company serves on the delivery date established

RP4: My company provides the quantities ordered

RP5: My company collaborates in new product launches

RP6: My company notifies in advance late deliveries or if quantities ordered are not served 
We used exploratory and confirmatory factor analysis to validate the measurement part of our model. As a result, the first proposed measure for Internal Integration (II1) was not considered satisfactory since the analysis detected that it was related with a different factor. The sixth question regarding the relative performance (RP6) was also dropped. Table A2 in the Appendix shows some of the results of the confirmatory factor analysis on the measurement part of the model.

Our construct model can be expressed in equation form as:

PERFORMANCE $=\beta_{1}($ INTERNAL INTEGRATION $)+\beta_{2}($ EXTERNAL INTEGRATION $)+\varepsilon$

The estimation of the model will allow us to test several hypothesis. We can relate them to the regression coefficients of the equation shown above and to the variancecovariance matrix of the two factors representing integration.

- Internal Integration affects Performance: For this to be true, the regression coefficient of Internal Integration, $\beta_{1}$, should be positive and statistically significant.

- External Integration affects Performance: The regression coefficient on External Integration, $\beta_{2}$, should be positive and statistically significant.

- Internal and External Integration are positively related: The covariance between the Internal and External Integration factors should be positive and statistically significant.

The next section reports the results of the estimation of the model and the tests of hypothesis.

\section{Results}

We estimated two complete structural equations models. In the first one, we studied the effect of the internal and external integration levels on the relative performance of the firm. In the second model, we considered the effect of both levels of integration on its absolute performance.

\subsection{Relative performance model}

Tables 4 and 5 summarise the estimation results for this model. The estimation is based on Maximum Likelihood and Normal theory.

We estimated this model twice. The values in columns 2 and 3 of tables 4 and 5 are based on data arising from the most collaborating relationship. The rest of the columns were calculated from data obtained from the least collaborating relationship. 
Table 4 shows the values of the structural coefficients of the relationship between the latent variables (and their associated significance tests statistics), the factor variancecovariance matrices (and their significance tests), and a couple of measures of fit of the model.

TABLE 4. Relative performance model: Construct

RELATIVE PERFORMANCE MODEL: Construct

\begin{tabular}{|c|c|c|c|c|}
\hline & \multicolumn{2}{|c|}{ Most Collaborating Relationship } & \multicolumn{2}{|c|}{ Least Collaborating Relationship } \\
\hline & \multicolumn{4}{|c|}{ Construct Coefficients } \\
\hline & $\begin{array}{c}\text { Internal } \\
\text { Integration }\end{array}$ & $\begin{array}{c}\text { External } \\
\text { Integration }\end{array}$ & $\begin{array}{c}\text { Internal } \\
\text { Integration }\end{array}$ & $\begin{array}{c}\text { External } \\
\text { Integration }\end{array}$ \\
\hline Relative & 0.020 & 0.120 & -0.020 & 0.077 \\
\hline Performance & $(0.406)$ & $(2.355)$ & $(-0.394)$ & $(1.228)$ \\
\hline \multicolumn{5}{|c|}{ Measures of fit } \\
\hline Chi-square & \multirow{2}{*}{\multicolumn{2}{|c|}{$\begin{array}{c}178.883 \\
(0.022)\end{array}$}} & \multirow{2}{*}{\multicolumn{2}{|c|}{$\begin{array}{l}264.930 \\
(<0.001)\end{array}$}} \\
\hline$(d . f=143)$ & & & & \\
\hline \multirow[t]{3}{*}{ CFI } & \multicolumn{2}{|c|}{0.965} & \multicolumn{2}{|c|}{0.864} \\
\hline & \multicolumn{4}{|c|}{ Factor variance-covariance matrix } \\
\hline & $\begin{array}{l}\text { Internal } \\
\text { Integration }\end{array}$ & $\begin{array}{l}\text { External } \\
\text { Integration }\end{array}$ & $\begin{array}{l}\text { Internal } \\
\text { Integration }\end{array}$ & $\begin{array}{l}\text { External } \\
\text { Integration }\end{array}$ \\
\hline $\begin{array}{l}\text { Internal } \\
\text { Integration }\end{array}$ & $\begin{array}{c}2.722 \\
(3.317)\end{array}$ & --- & $\begin{array}{c}2.716 \\
(3.310)\end{array}$ & --- \\
\hline External & 1.560 & 3.195 & 0.835 & 1.864 \\
\hline Integration & (3.016) & $(3.275)$ & (2.354) & (3.244) \\
\hline
\end{tabular}

Note: Test statistics are inside the parenthesis. We report the probability values of the chi-square test and the ratio between the coefficient and its standard error for the estimates.

Table 5 reports the results from the measurement part of the model: The value of the factor loading of each measure and the corresponding significance statistic.

The model has an acceptable fit. If estimated with data from the most collaborating relationship, the chi-square goodness of fit is 178.883 with 143 degrees of freedom, which corresponds to a P-value of 0.022 . The CFI (Comparative Fit Index) is 0.965 , a very satisfactory value. The fit is worse when the same model is estimated with the data corresponding to the least collaborating relationship. The CFI is only 0.864 , a slightly low value ${ }^{2}$.

\footnotetext{
${ }^{2}$ The CFI measure works well in practically all the contexts, while the value of the chi-square statistic is affected by sample size.
} 
Internal and External Integration are positively related. The covariance among them is 1.560 in the most collaborating relationship, and 0.835 in the least collaborating one. Both values are significantly different from zero. The regression coefficient of Internal Integration is never significantly different from zero. And, the External Integration coefficient is significantly different from zero for the most collaborating relationship, while it is not statistically different from zero for the least collaborating relationship.

TABLE 5. Relative performance model: Measurement

RELATIVE PERFORMANCE MODEL: Measurement

\begin{tabular}{|c|c|c|c|c|}
\hline \multirow[b]{2}{*}{$\begin{array}{l}\text { Internal } \\
\text { Integration }\end{array}$} & \multicolumn{2}{|c|}{ Most Collaborating Relationship } & \multicolumn{2}{|c|}{ Least Collaborating Relationship } \\
\hline & $\begin{array}{c}\text { Factor } \\
\text { Loading }\end{array}$ & $\begin{array}{c}\text { Test } \\
\text { Statistic }\end{array}$ & $\begin{array}{c}\text { Factor } \\
\text { Loading }\end{array}$ & $\begin{array}{c}\text { Test } \\
\text { Statistic }\end{array}$ \\
\hline II2 & 1.00 & --- & 1.00 & --- \\
\hline II3 & 1.010 & 8.148 & 1.014 & 8.146 \\
\hline 114 & 1.287 & 7.598 & 1.270 & 7.502 \\
\hline 115 & 1.415 & 7.108 & 1.416 & 7.084 \\
\hline 116 & 1.366 & 7.782 & 1.370 & 7.767 \\
\hline 117 & 1.293 & 7.071 & 1.289 & 7.021 \\
\hline \multicolumn{5}{|l|}{$\begin{array}{l}\text { External } \\
\text { Integration }\end{array}$} \\
\hline El1 & 1.00 & --- & 1.00 & --- \\
\hline El2 & 1.228 & 6.347 & 0.982 & 6.060 \\
\hline El3 & 1.465 & 7.689 & 1.132 & 6.196 \\
\hline El4 & 1.177 & 5.874 & 1.003 & 6.210 \\
\hline El5 & 1.370 & 7.691 & 1.219 & 7.572 \\
\hline El6 & 1.352 & 6.793 & 0.868 & 5.693 \\
\hline El7 & 1.411 & 7.288 & 1.046 & 6.573 \\
\hline El8 & 1.481 & 7.774 & 1.008 & 5.789 \\
\hline \multicolumn{5}{|l|}{ Relative } \\
\hline \multicolumn{5}{|c|}{ Performance } \\
\hline RP1 & 1.00 & --- & 1.00 & --- \\
\hline RP2 & 1.158 & 4.488 & 0.995 & 5.695 \\
\hline RP3 & 1.076 & 4.470 & 1.033 & 5.918 \\
\hline RP4 & 0.773 & 3.247 & 0.734 & 4.596 \\
\hline RP5 & 0.610 & 2.483 & 0.597 & 3.128 \\
\hline
\end{tabular}


The factor loadings are quite similar for both types of relationships, which further validates our choice of instruments ${ }^{3}$. The values are close to one in all cases and all of them are statistically significant.

\subsection{Absolute performance model}

The numerical results for this model are summarised in tables 6 and 7. The CFI measures of fit are also good, for both types of relationships. Again, Internal and External Integration exhibit a positive and significantly different from zero covariance (also in both cases). As it can be appreciated, both types of integration -internal and external- seem to have a direct effect on Absolute Performance. This is not completely true when we use data from the most collaborating relationship, since the test statistic associated to the regression coefficient of Internal Integration is only 1.625 .

TABLE 6. Absolute performance model: Construct

ABSOLUTE PERFORMANCE MODEL: Construct

\begin{tabular}{|c|c|c|c|c|}
\hline & \multicolumn{2}{|c|}{ Most Collaborating Relationship } & \multicolumn{2}{|c|}{ Least Collaborating Relationship } \\
\hline & \multicolumn{4}{|c|}{ Construct Coefficients } \\
\hline & $\begin{array}{c}\text { Internal } \\
\text { Integration }\end{array}$ & $\begin{array}{c}\text { External } \\
\text { Integration }\end{array}$ & $\begin{array}{c}\text { Internal } \\
\text { Integration }\end{array}$ & $\begin{array}{c}\text { External } \\
\text { Integration }\end{array}$ \\
\hline Absolute & \multirow{2}{*}{$\begin{array}{c}0.221 \\
(1.625)\end{array}$} & \multirow{2}{*}{$\begin{array}{c}0.742 \\
(4.822)\end{array}$} & \multirow{2}{*}{$\begin{array}{c}0.582 \\
(3.170)\end{array}$} & \multirow{2}{*}{$\begin{array}{c}0.670 \\
(3.001)\end{array}$} \\
\hline Performance & & & & \\
\hline & \multicolumn{4}{|c|}{ Measures of fit } \\
\hline Chi-square & \multirow{2}{*}{\multicolumn{2}{|c|}{$\begin{array}{c}195.201 \\
(0.002)\end{array}$}} & \multirow{2}{*}{\multicolumn{2}{|c|}{$\begin{array}{l}233.064 \\
(<0.001)\end{array}$}} \\
\hline$(d . f=144)$ & & & & \\
\hline \multirow[t]{3}{*}{$\mathrm{CFI}$} & \multicolumn{2}{|c|}{0.957} & \multicolumn{2}{|c|}{0.916} \\
\hline & \multicolumn{4}{|c|}{ Factor variance-covariance matrix } \\
\hline & $\begin{array}{l}\text { Internal } \\
\text { Integration }\end{array}$ & $\begin{array}{l}\text { External } \\
\text { Integration }\end{array}$ & $\begin{array}{l}\text { Internal } \\
\text { Integration }\end{array}$ & $\begin{array}{l}\text { External } \\
\text { Integration }\end{array}$ \\
\hline Internal & 2.720 & & 2.746 & \\
\hline Integration & $(3.308)$ & & $(3.330)$ & \\
\hline External & 1.490 & 3.200 & 0.796 & 1.857 \\
\hline Integration & $(2.932)$ & (3.279) & $(2.265)$ & (3.669) \\
\hline
\end{tabular}

Note: Test statistics are inside the parenthesis. We report the probability values of the chi-square test and the ratio between the coefficient and its standard error for the estimates.

\footnotetext{
${ }^{3}$ The factor loading of the first measure of each factor is set to one. This makes possible to estimate the variance of the factor.
} 
TABLE 7. Absolute performance model: Measurement

ABSOLUTE PERFORMANCE MODEL: Measurement

\begin{tabular}{|c|c|c|c|c|}
\hline \multirow[b]{2}{*}{$\begin{array}{l}\text { Internal } \\
\text { Integration }\end{array}$} & \multicolumn{2}{|c|}{ Most Collaborating Relationship } & \multicolumn{2}{|c|}{ Least Collaborating Relationship } \\
\hline & $\begin{array}{c}\text { Factor } \\
\text { Loading }\end{array}$ & $\begin{array}{c}\text { Test } \\
\text { Statistic }\end{array}$ & $\begin{array}{c}\text { Factor } \\
\text { Loading }\end{array}$ & $\begin{array}{c}\text { Test } \\
\text { Statistic }\end{array}$ \\
\hline IIP2 & 1.00 & --- & 1.00 & --- \\
\hline IIP3 & 1.013 & 8.182 & 1.012 & 8.213 \\
\hline IIP4 & 1.263 & 7.489 & 1.258 & 7.557 \\
\hline IIP5 & 1.420 & 7.088 & 1.412 & 7.134 \\
\hline IIP6 & 1.354 & 7.749 & 1.347 & 7.817 \\
\hline IIP7 & 1.251 & 6.684 & 1.242 & 6.709 \\
\hline \multicolumn{5}{|l|}{$\begin{array}{l}\text { External } \\
\text { Integration }\end{array}$} \\
\hline El1 & 1.00 & --- & 1.00 & --- \\
\hline El2 & 1.234 & 6.474 & 0.980 & 6.089 \\
\hline El3 & 1.453 & 7.705 & 1.140 & 6.212 \\
\hline El4 & 1.196 & 5.967 & 1.005 & 6.193 \\
\hline El5 & 1.348 & 7.648 & 1.218 & 7.533 \\
\hline El6 & 1.367 & 6.748 & 0.872 & 5.617 \\
\hline El7 & 1.410 & 7.306 & 1.047 & 6.547 \\
\hline El8 & 1.511 & 7.840 & 1.055 & 6.044 \\
\hline \multicolumn{5}{|c|}{$\begin{array}{l}\text { Absolute } \\
\text { Performance }\end{array}$} \\
\hline AP1 & 1.00 & --- & 1.00 & --- \\
\hline AP2 & 1.139 & 11.920 & 0.991 & 18.155 \\
\hline AP3 & 1.022 & 9.488 & 0.828 & 11.386 \\
\hline AP4 & 0.729 & 5.823 & 0.833 & 8.072 \\
\hline AP5 & 0.788 & 7.464 & 0.718 & 7.292 \\
\hline
\end{tabular}

Again, factor loadings are all very close to one and very similar across the two types of relationships.

\subsection{Hypothesis testing}

Evidence suggests that internal and external integration are significantly correlated in both models and for both relationships groups. The covariance between Internal and External Integration is 0.835 with a test statistic of 2.354 in the Relative Performance 
case, and 0.796 with a test statistic of 2.265 in the Absolute Performance model. Firms achieve a relatively high degree of internal integration before implementing SCM.

The structural equation model in table 4 shows that external integration leads to a better relative performance, but internal integration does not. This model only fits when there is a high level of external integration (in other words, for the most collaborating relationship). In the least collaborative relationship, there is not external integration, and therefore, the model does not fit.

The absolute performance model (see table 6) suggests that the level of external integration leads to a better absolute performance. This model also shows that the level of internal integration only leads to a better absolute performance when there is not a high level of external integration (the internal integration coefficient is only significant for the least collaborating relationships). However, when the company also integrates externally, the level of external integration has such an important effect on performance that it annuls (or reduces) the effect of the internal integration.

\section{Conclusions and contributions}

There are three generic results on the integration-performance relationship that can be derived from this analysis, namely:

1. Firms achieve a relatively high degree of internal integration (collaboration among internal processes) before implementing SCM.

2. When companies achieve a high level of internal integration (stage II in figure 1), this level of integration leads to a better absolute performance. A high level of collaboration among internal processes contributes to achieving cost, stockouts and lead time reductions. However, this internal collaboration does not lead to gaining a competitive advantage. This could be due to the fact that there are already many companies that have achieved this stage. In our sample, the percentage of relationships which had a high level of internal integration was $72,1 \%$ (a cluster analysis revealed that $43,4 \%$ of the sample relationships were in stage II and $28,7 \%$ in stage III).

3. When companies achieve stage III (internal and external integration), the external integration level leads to a better absolute and relative performance. External collaboration among supply chain members contributes to achieving costs, stock-outs and lead-time reductions, but also to gaining a competitive advantage. When companies extend the level of internal integration to their supply chain members, they can perform better than their competitors in the 
following performance variables: response to customer's needs and requirements, response to special requirements, accomplishment of quantities and delivery dates, and collaboration in new product launches. SCM contributes to gaining a better competitive position because there are few companies that have achieved this stage (only $28,7 \%$ of the sample's relationships were classified in stage III). This might not continue to be true in the future, when more companies will have implemented SCM. SCM will become a prerequisite to survive in the highly competitive environment.

With respect to the studies mentioned in the literature review, our results confirm that internal and external integration are correlated. We have also corroborated that both levels of integration lead to a better absolute performance. Our study, however, has contributed to the Logistics Science Knowledge showing that internal integration by itself is not sufficient to gain a competitive advantage: There is the need to extend this integration to suppliers and customers.

Our results differ from those obtained by Stank, Keller \& Daugherty (2001). They found that internal collaboration led to a better competitive position, while external collaboration did not.

Stank, Keller \& Daugherty (2001) considered very heterogeneous industries in the same model, and this could be the reason why they failed to demonstrate that external integration leads to a better relative performance. The level of SCM development varies considerably from one sector to another. For example, the automotive industry is well known as the pioneer in the implementation of SCM practices. We believe that in the car industry, SCM does not lead to a competitive advantage; it is a prerequisite to survive, and almost all the companies have implemented it. If Stank, Keller \& Daugherty (2001) had considered different models for different sector structures, they might have obtained very different results. In fact, Stank, Crum \& Arango (1999) conducted a similar study in the food industry, and they found that interfirm supply chain co-ordination (external integration) led to a better absolute and relative performance.

Our study has some limitations. One of them is that our study has not considered other important members of the grocery supply chain such as grocery retailers, Third Party Logistics, manufacturers' suppliers, etc. The study has focused only on the manufacturer-retailer relationship from the manufacturer point of view. Further research should focus on other grocery supply chain relationships. 
Another limitation is that intra-firm co-ordination has been considered only on one internal relationship: the Production-Logistics interface. Other functions, such as Purchasing and Marketing should be considered in future research.

We have only considered the effect of inter-firm co-ordination from the perspective of the provider (as most of the studies do). However, satisfaction with service performance should have also been assessed from the customer perspective. To alleviate the concern about the biased performance assessment by providers, future research should collect data on both sides of the relationship.

Finally, we believe that the contribution of SCM to gaining a competitive advantage is affected by the level of SCM implementation in the industry. Future research should apply this study to other sectors in order to consider different sector structures and different levels of SCM implementation. 


\section{References}

Arbuckle, J. (1997): AMOS User's Guide Version 3.6. Chicago: Smallwaters Corp.

Armstrong, J.S. \& Overton, T.S. (1977): "Estimating non-response bias in mail surveys"; Journal of Marketing Research; Vol.14 no.3; pages 396- 402.

Bentler, P. M. (1995): EQS Structural Equations Program Manual. Encino, CA: Multivariate Software, Inc.

Byrne, S.M. \& Javad, S. (1992): "Integrated Logistics Information Systems (ILIS): Competitive advantage or increased cost"; Council of Logistics Management Annual Conference Proceedings; Oak Brook, Illinois; pages 55-73.

Christiansee, E. \& Kumar, K. (2000): "ICT-enabled coordination of dynamic supply webs"; International Journal of Physical Distribution and Logistics Management; Vol.30 no.3/4; pages 268-285.

Christopher, M. (1998): Logistics and Supply Chain Management: Strategies for reducing cost and improving service; Financial Times Pitman Publishing.

Cooper, M.C. (1993): "International Supply Chain Management: Implications for the bottom line"; Proceedings of the Society of Logistics Engineers; Hyattsville, MD: Society of Logistics Engineers.

Daugherty, P.J.; Ellinger, A.E. \& Gustin, C.M. (1998): "Integrated Logistics: The performance connection"; Council of Logistics Management Annual Conference Proceedings; Anaheim, California; pages 383-388.

Daugherty, P.J.; Ellinger, A.E. \& Rogers, D.S. (1995): "Information accessibility: Customer responsiveness and enhanced performance"; International Journal of Physical Distribution and Logistics Management; Vol.25 no.1; pages 4-17.

Daugherty, P.J.; Sabath, R.E. \& Rogers, D.S. (1992): "Competitive advantage through customer responsiveness"; Logistics and Transportation Review; Vol.28 no.3; pages 257-271.

Distribución Anual (2002): “Anuario de la Distribución 2001”; Vol. 1.

Ellinger, A.; Daugherty, P. \& Keller, S. (2000): "The relationship between marketing/ logistics interdepartmental integration and performance in U.S. manufacturing firms: An empirical study"; Journal of Business Logistics; Vol.21 no.1; pages 1-22. 
Ellinger, A.; Taylor, J.C. \& Daugherty, P.J. (2000): "Programas de reposición automática y niveles de involucramiento: Su impacto en la performance"; The International Journal of Logistics Management; Vol.10 no.1; pages 29-40.

Ellram, L.M. \& Cooper, M.C. (1993): "The relationship between supply chain management and Keiretsu"; The International Journal of Logistics Management; Vol.4 no.1; pages 1-12.

Fomento de la Producción (2000): “España 25.000 (DataBase)”; Edition 2000.

Fox, R.; Crask, M. \& Kim, J. (1988): "Mail survey response rate: A Metaanalysis of selected techniques for inducing response"; Public Opinion Quarterly 52; no.1; pages 467-491.

Groves, G. \& Valsamakis, V. (1998): "Supplier-customer relationships and company performance"; The International Journal of Logistics Management; Vol.9 no.2; pages 51-63.

Gustin, C.M.; Stank, T.P. \& Daugherty, P.J. (1994): "Computerization: Supporting integration"; The International Journal of Physical Distribution and Logistics Management; Vol.24 no.1; pages 11-16.

Hair, J.H.; Anderson, R.E.; Tatham, R.L. \& Black, W.C. (1999): Análisis multivariante; Prentice Hall Iberia; $5^{\mathbf{a}}$ ed.; Madrid.

Jöreskog, K. G. \& Sörbom D. (1993): LISREL 8 User's Reference Guide, Chicago: Scientific Software International, Inc.

Lambert, D.M. \& Harrington, T.C. (1990): "Measuring nonresponse in customer service mail surveys"; Journal of Business Logistics; Vol.11 no.2; pages 5-25.

Larson, P.D. (1994): "An empirical study of inter-organizational functional integration and total costs"; Journal of Business Logistics; Vol.15 no.1; pages 153-169.

Porter, M.E. (1985): Competitive advantage; The Free Press; New York.

SAS Institute Inc. (1990): SAS Technical Report P-200: CALIS and LOGISTIC Procedures Release 6.04, Cary NC: SAS Institute Inc.

Scannell, T.V.; Vickery, S.K. \& Dröge, C.L. (2000): "Upstream supply chain management and competitive performance in the automotive supply industry"; Journal of Business Logistics; Vol.21 no.1, pages 23-48.

Scott, C. \& Westbrook, R. (1991): "New strategic tools for supply chain management"; International Journal of Physical Distribution and Materials Management; Vol.21 no.1; pages 23-33. 
Shapiro, R.D. (1984): "Get leverage from logistics"; Harvard Business Review; Vol.62 no.3; pages 119-126.

Stank, T.P.; Crum, M. \& Arango, M. (1999): "Benefits of inter-firm coordination in food industry supply chains"; Journal of Business Logistics; Vol.20 no.2; pages 21-41.

Stank, T.P.; Daugherty, P.J. \& Autry, C. (1999): "Collaborative planning: Supporting automatic replenishment programs"; Supply Chain Management; Vol.4 no.2; pages 7585.

Stank, T.P.; Daugherty, P.J. \& Ellinger A. (2000): "Integración Marketing/Logística y performance de la empresa"; The International Journal of Logistics Management; Vol.10 no.1; pages 13-27.

Stank, T.P.; Keller, S. \& Daugherty, P. (2001): "Supply chain collaboration \& logistical service performance"; Journal of Business Logistics; Vol.22 no.1; pages 29-48.

Stevens, G.C. (1989): "Integrating the supply chain"; International Journal of Physical Distribution and Materials Management; Vol.19 no.8; pages 3-8.

Stock, G.N.; Greis, N.P. \& Kasarda, J.D. (1998): "Logistics, strategy and structure: A conceptual framework"; International Journal of Operations and Production Management; Vol.18 no.1; pages 37-52.

The Global Logistics Team at Michigan State University (1995): World Class Logistics: The challenge of managing continuous change; Council of Logistics Management; Oak Brook, Illinois.

Vargas, G.; Cardenas, L. \& Matarranz, L. (2000): "Internal and external integration of assembly manufacturing activities"; International Journal of Operations and Production Management; Vol.20 no.7; pages 809-822. 


\section{Appendix}

In this appendix we show several tables that illustrate the characteristics of our data and the quality of the variables used as indicators in our factor model.

\section{TABLE A1. Sample characteristics}

\section{SAMPLE CHARACTERISTICS}

\section{Sales volume (million $€$ )}

More than 600

$401-600$

$201-400$

$3,7 \%$

$101-200$

$8 \quad 12,5 \%$

$51-100$

$24 \quad 37,5 \%$

$30-50$

$15 \quad 23,4 \%$

$13 \quad 20,3 \%$

\section{Sectors}

$\begin{array}{lcc}\text { Chemicals - Perfumery and detergents } & 12 & 18,8 \% \\ \text { Food - Fish and preserved products } & 6 & 9,4 \% \\ \text { Food - Dairy products } & 5 & 7,8 \% \\ \text { Food - Wheat } & 4 & 6,3 \% \\ \text { Food - Dried fruit } & 2 & 3,1 \% \\ \text { Food - Meats } & 5 & 7,8 \% \\ \text { Food - Preserved vegetables } & 3 & 4,7 \% \\ \text { Food - Drinks } & 15 & 23,4 \% \\ \text { Food - Oils } & 4 & 6,3 \% \\ \text { Food - Varied products } & 8 & 12,5 \%\end{array}$

The next table shows the Comparative Fit Index (CFI) of the confirmatory factor analysis that we performed separately on each set of indicators of the latent factors. The CFI are quite good in all the cases considered. Factor loadings were always sound and significant, and therefore we concluded that the confirmatory factor analysis supported the validity of the items representing each construct. The Lagrange Multiplier (LM) tests indicated that the measurement errors of some of these indicators were strongly correlated and therefore we modelled that correlation explicitly in all the subsequent estimations. 
Table A2. Comparative Fit Index of the measurement models

\begin{tabular}{|l|c|c|c|c|}
\hline & $\begin{array}{c}\text { Internal } \\
\text { Integration }\end{array}$ & $\begin{array}{c}\text { External } \\
\text { Integration }\end{array}$ & $\begin{array}{c}\text { Relative } \\
\text { Performance }\end{array}$ & $\begin{array}{c}\text { Absolute } \\
\text { Performance }\end{array}$ \\
\hline Strongest & 0.991 & $1.000^{4}$ & 0.934 & 0.977 \\
Relationship & $(64$ cases $)$ & $(64$ cases $)$ & $(63$ cases $)$ & (62 cases $)$ \\
\hline Weakest & & 0.900 & 0.977 & 0.984 \\
Relationship & ------ & $(64$ cases $)$ & $(63$ cases $)$ & (62 cases $)$ \\
\hline
\end{tabular}

\footnotetext{
${ }^{4}$ This is a rounded number. The true value is very close to -but lower than- one.
} 